угарным и углекислым газом. Помимо этого возникает общее обескислороживание атмосферного воздуха.

$$
* * *
$$

1. Акимов В.А. Основы анализа и управления риском в природной и техногенной сферах: Учебное пособие / В.А. Акимов, В.В. Лесных, Н.Н. Радаев. - М.: Деловой экспресс, 2016г.;

2. Теребнев В.В. Пожарная тактика. Книга 9. Пожаротушение в зданиях / В.В.Теребнев. - Екатеринбург: КФ ПАО «Издательство «Калан», 2013 г.;

3. Швырков С.А. Пожарная безопасность технологических процессов: учебник / и др.; под общ. ред. С.А. Швыркова. - М.: Академия ГПС МЧС России, 2017. - 388 с.;

4. Официальный сайт МЧС: Статистика - www.mchs.gov.ru/stats/

\title{
Старожилов В.T. \\ Ландшафтная организация и районирование окраинных морей Тихоокеанского ландшафтного пояса геосистемы Восток России - Мировой океан
}

Дальневосточный Федеральньй университет (Россия, Владивосток)

doi: 10.18411/trnio-12-2021-333

\section{Аннотация}

Работа представляет собой продолжение комплексных исследований в целом сформировавшейся ландшафтной школы профессора В.Т. Старожилова (doi:10.24411/1728323X-2020-13079; doi:10.18411/lj-05-2020-26). Рассматривается организация и ландшафтное районирование окраинных морей Тихоокеанского ландшафтного пояса: Японского, Охотского, Берингового. Они сопряженны с Сихотэ-Алинской, Нижнеамурской, КамчатскоКурильской, Сахалинской и другими ранее нами рассмотренными орогенными континентальными ландшафтными областями Тихоокеанского ландшафтного пояса России (doi: 10.18411/lj-01-2021-32). Констатируется, что на основе применения ландшафтной методологии, на основе сопряженного анализа и синтеза межкомпонентных связей с учетом окраинно-континентальной дихотомии и данных по орогеническому, орографическому, климатическому и биогенному факторам формирования географически единых территорий, проведено среднемасштабные изучение и формулирование организации и районирование окраинных морей Тихоокеанского ландшафтного пояса (Российская часть) и выделены округа, провинции и области. Оно является одной из базовых моделей «фундаментом» для построения гармонизированных с природой и связанных с океаном индикационных, картографических, экологических, биологических, биогеохимических, биоресурсных, минерально-сырьевых и других отраслевых, научных моделей, в целом пространственного развития геосистемы Восточная Россия-Мировой океан. Отмечается, что при исследовании применялись компьютерные технологии векторно-слоевого ландшафтного метода, которые в свою очередь создают платформу для разработки планов и проектов научных исследований и освоения, создания паспортов природы. Они также является платформой для обучения студентов. Приводятся данные о картографической обеспеченности современными векторнослоевыми цифровыми материалами.

Ключевые слова: районирование, провинции, области, освоение, ландшафт, пояс, окраинное море.

\section{Abstract}

Work is a continuation of comprehensive studies in general formed by the Landscape School of Professor V.T. Starozhilov (DOI: 10.24411 / 1728-323x-2020-13079; DOI: 10.18411 / LJ-052020-26). The organization and landscape zoning of the seaside seas of the Pacific landscape belt are considered: Japanese, Okhotsk, Bering. They are associated with the Sikhote-Alin, Nizhnyamur, Kamchatka-Kuril, Sakhalin and other previously considered orogenous continental landscaped areas 
of the Pacific Landscaping Belt of Russia (DOI: 10.18411 / LJ-01-2021-32). It is stated that, based on the use of landscape methodology, based on the conjugated analysis and synthesis of intercompontential bonds, taking into account the abundant-continental dichotomy and data on the orogenic, orographic, climatic and biogenic factors of the formation of geographically unified territories, the average maintenance and formulation of the organization and the zoning of the seasons of the Pacific Landscape belt (Russian part) and distinguished district, provinces and regions. It is one of the base models "foundation" to build harmonized with nature and the oceanrelated indication, cartographic, environmental, biological, biogeochemical, biorestic, mineral and other sectoral, scientific models, in general, the spatial development of the geosystem of the Eastern Russia-World Ocean . It is noted that in the study, computer technologies of the vector-layered landscape method were used, which in turn create a platform for developing plans and projects of scientific research and development. They are also a platform for students learning. The data on the cartographic provision of modern vector-layer digital materials are given.

Keywords: zoning, provinces, regions, development, landscape, belt, outskirts of the sea.

Введение. Настоящие исследования по организации и ландшафтному районированию геосистемы Восток России - Мировой океан представляют собой продолжение комплексных исследований Тихоокеанского международного ландшафтного центра ДВФУ, ландшафтной школы профессора В.Т. Старожилова, которая способна решать практические задачи по освоению территорий Тихоокеанской России и развитию теоретической базы ландшафтной географии (https://www.dvfu.ru/expertise/news/science/landshaftnaya _shkola_professora_starozhilova/, doi:10.24411/1728-323X-2020-13079, doi:10.18411/1j-05-202026), работ по Тихоокеанскому ландшафтному поясу (doi:10.18411/a-2017-089), (https://doi.org/10.18411/a-2017-089), а также разработанных парадигм: общей Дальневосточной ландшафтной парадигмы и Дальневосточной ландшафтной парадигмы индикации и планирования (doi:10.18411/lj-05-2020-26), разработок по картографическому оцифрованному ландшафтному обеспечению индикации, планирования и геоэкологического мониторинга юга Тихоокеанского ландшафтного пояса России (doi:10.18411/1j-05-2020-27), а также по «Ландшафтному звену выстраивания планирования и развития экономических, градостроительных и др. структур осваиваемых территорий» (doi: 10.18411/1j-09-2020-36), «О необходимости принятия к практической реализации новую ландшафтную стратегию к пространственному развитию геосистемы континент-Мировой океан» (doi: 10.24412/1728323X-2021-2-36-43) и разработок «К пространственному развитию территорий: районирование Тихоокеанского ландшафтного пояса геосистемы Восток России- Мировой океан ( doi.org/10.24412/1728-323X-2021-4-58-69).

Комплексное изучение геосистемы континент-Мировой океан, выделение ландшафтной структуры Тихоокеанского ландшафтного пояса, а также появление картографических документов (в том числе ландшафтных карт) имеет базовое значение при формировании стратегии к пространственному развитию и освоению геосистемы континентМировой океан. Именно ландшафтный пояс, включающий Сихотэ-Алинскую, Нижнеамурскую, Камчатско-Курильскую, Сахалинскую и другие ландшафтные области и сопряженные с ними окраинные моря представляет собой значимую основу для выполнения задач науки и практики пространственного освоения и развития территорий континентального обрамления Тихого океана, окраинных морей и использования материалов в освоении Мирового океана. Он, как планетарная ландшафтная структура является базовой моделью «фундаментом» для построения гармонизированных с природой континента и связанных с океаном индикационных, картографических, экологических, биологических, биогеохимических, биоресурсных, минерально-сырьевых, экологических, сельскохозяйственных, градостроительных и других отраслевых моделей освоения, в целом пространственного развития и освоения этой обширной тихоокеанской зоны. Однако, несмотря на большую значимость природы пояса для развития и освоения Востока России, ландшафтная изученность пояса мозаичная и это в том числе касается вопросов его 
районирования. Ландшафтное районирование проведено только по континентальной его части (doi.org/10.24412/1728-323X-2021-4-58-69), по второй его морской части мелкосреднемасштабное районирование сверху вниз не проводилось и это отражается на решение вопросов пространственного его развития и освоения. Все это и определило актуальность выполненной работы.

Объект исследований - Тихоокеанский ландшафтный пояс, морское звено его диалектической пары, представленное Японским, Охотским, Беринговым окраинными морскими территориями (doi:10.18411/a-2017-089), (https://doi.org/10.18411/a-2017-089), pис. $1)$.

Выделен Дальневосточной ландшафтной школой профессора В.Т. Старожилова на основе комплексного ландшафтного подхода в понимании зоны перехода континента к океану, основанном на региональном междисциплинарном синтезе, анализе и оценке компонентов его внутреннего содержания (включает фундамент, рельеф, воды, климат, почвы, растительность, биоценозы) и применения ландшафтной методологии изучения территорий, на основе учета взаимодействия, взаимообусловленности и взаимопроникновения друг в друга компонентов, на основе изучения ландшафтов в условиях окраинно-континентальной дихотомии, на основе изучения орогенического, орографического, климатического взаимодействующих между собой факторов. Он имеет базовое значение при природопользовании и решения вопросов экологически чистого пространственного развития геосистемы Восточная Россия - Мировой океан.

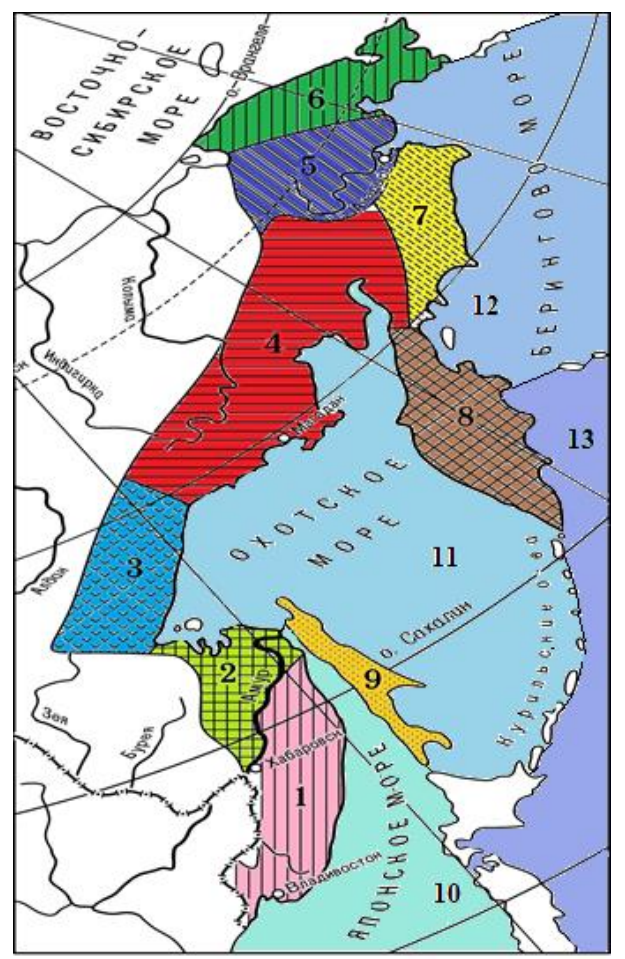

Рисунок 1. Карта Тихоокеанского ландшафтного пояса России, его областей (Старожилов, 2018) Области пояса: 1. Сихотэ-Алинская; 2. Нижнеамурская; 3. Приохотская; 4.Колылмккая; 5. Анадырьская; 6. Чукотская; 7. Корякская; 8. Камчатско-Курильская; 9. Сахалинская; 10. Японская; 11. Охотская; 12. Беринговая. 13. Тихоокеанская

Цель публикации - обосновать в Российской науке необходимость на основе применения ландшафтного метода выделять сверху вниз и применять в науке и практике ландшафтные области, провинции, округа как индивидуальные важные таксоны организации и районирования окраинных морей Тихого океана, как внутреннее содержание Тихоокеанского ландшафтного пояса, как природные структуры диалектической пары геосистемы континент-Мировой океан; обосновать их базовый комплексный характер как структур ландшафтной основы-модели экологически чистого освоения и использование 
материалов при решении вопросов пространственного развития системы континентМировой океан. Ландшафтные таксоны районирования (округа, провинции, области - как внутреннее содержание морского звена Тихоокеанского ландшафтного пояса) рассматривать как единицы природного «фундамента» для построения гармонизированных с континентальной природой и океаном региональных и планетарных научных и практикмоделей освоения (индикационных, картографических, экологических, биологических, биогеохимических, биоресурсных, минерально-сырьевых, краеведческих, экологических, сельскохозяйственных, экономических, социальных, градостроительных и других) к пространственному развитию территорий.

В целом при районировании морской части Тихоокеанского ландшафтного пояса геосистемы Восточная Россия - Мировой океан выделяются ландшафтные округа, провинции, области. Это делается на среднемасштабном уровне.

Под ландшафтом понимается природное тело, имеющие высотную (верхнюю), глубинную (нижнюю) и горизонтальную (площадную) границы, с внутренним содержанием взаимосвязанных, взаимообусловленных и взаимопроникающих друг в друга компонентов (фундамент, рельеф, воды, биоценозы, климат, почвы, растительность) с дифференциацией, подчиняющейся высотной и широтной зональности, и организованных ответственными за них орогеническим, орографическим, климатическим факторами в определенных зональных и азональных условиях в каждый момент своего существования.

Под ландшафтным округом понимается обособленная внутри провинции структура, включающая ландшафты и их виды с дифференциацией, подчиняющейся высотной и широтной зональности, и организованных ответственными за них орогеническим, орографическим, климатическим и биогенным факторами в определенных зональных и азональных условиях в каждый момент своего существования.

Под ландшафтной провинцией понимается обособленная внутри области структура, включающая ландшафты подклассов и родов, определяемые высотностью, типами биоценозов, рельефом и вещественными комплексами фундамента, с дифференциацией, подчиняющейся высотной и широтной зональности и организованных ответственными за них орогеническим, орографическим, климатическим и биогенным факторами в определенных зональных и азональных условиях в каждый момент своего существования.

Под ландшафтной областью понимается обособленная внутри пояса структура, включающая ландшафты одного класса, связанные с крупными тектоническими единицами и орографическими элементами (шельфовыми структурами, низменностями) одного зонального или азонального типа и по этому признаку является частью определенной зоны, подчиняющейся высотной и широтной зональности, и организованных ответственными за них орогеническим, орографическим, климатическим и биогенным факторами в определенных зональных и азональных условиях в каждый момент своего существования.

Под ландшафтным поясом понимается - азональный пояс ландшафтной сферы с генетически единым структурно-тектоническим положением в зоне окраинноконтинентальной дихотомии системы океан-континент и характеризующегося аккреционной природой фундамента ландшафтных (в Российской части пояса Сихотэ-Алинской, Нижнеамурской, Приохотской, Сахалинской, Камчатско-Курильской, Чукотской, Японской, Охотской и др.) географических областей (структур) с климатическим, биогенным внутренним содержанием, подчиняющимся высотной и широтной зональности и эволюционирующим под действием взаимодействующих, взаимосвязанных и взаимопроникающих друг в друга орогенического, орографического, климатического и биогенного факторов в определенных зональных и азональных условиях в каждый момент своего существования.

Материалы и методы. Общей методологической основой исследований используется комплексная основа ландшафтного научно-практического направления, разработанная Дальневосточной ландшафтной школой профессора В.Т. Старожилова, направленного на рациональное освоение и использование территорий, минимизацию 
глобальных и региональных последствий изменения природы и общества, поиск и внедрение инновационных подходов в устойчивом, экологически сбалансированном и безопасном развитии обширного региона. Основанной на анализе, синтезе и оценке не только теоретических результатов научных исследований, но и практической реализации ландшафтного подхода в различных отраслях производства Тихоокеанского ландшафтного пояса России [3].

При районировании использовалась методология новой ландшафтной стратегии к пространственному развитию геосистемы континент-Мировой океан (doi:10.18411/lj-042021-23). Это, прежде всего, сформулированные базовые подходы к её разработке на основе современных, прогрессивных результатов ландшафтного научно-практического направления, разработанного Дальневосточной ландшафтной школой профессора В.Т. Старожилова. Они включают рациональное освоение и использование территорий, минимизацию глобальных и региональных последствий изменения природы и общества, поиск и внедрение инновационных подходов в устойчивом, экологически сбалансированном и безопасном развитии обширного региона и пространственное развитие геосистемы континент-Мировой океан.

Примененная общая методология показала, что при понимании ландшафтного пояса, как диалектической пары, представленной горной и сопряженной (территориально, генетически и эволюционно) с ней окраинной морской ландшафтной структурами, встает необходимость целостного классификационного рассмотрения их структур. Они взаимосвязаны, взаимопроникают друг в друга, взаимообусловлены и генетически развиваются под действием орогенического, орографического, климатического и биогенного факторов. Они связаны генетически между собой историческим ходом развития как единное целое.

Главным критерием классификационного выделения крупных современных (ландшафтных округов, провинций, областей) морских, как и горных (округов, провинций, областей) структур в настоящей работе является ландшафтный и генетический принцип. Это можно выразить словами Милькова «генетическим единством обладают все категории региональной таксономической лестницы от района до зоны и страны включительно. И это генетическое единство всех единиц выражается в общности истории развития и формирования основных существенных черт ландшафта данной градации». При этом «главной причиной, определяющей обособление и дальнейшее формирование физикогеографических единиц всегда является геолого-геоморфологическая основа» $[1,2]$. Поэтому, учитывая опыт по районированию территорий России, в авторских исследованиях мы основывались на представлениях генетического своеобразия развития территории Тихоокеанского ландшафтного пояса России с учетом установленных нами глубинных корней окраинно-континентальной дихотомии, законе фундаментального дуализма суши и моря, парности в организации и функционировании, единстве и противоположности приморских и континентальных ландшафтов и геосистем.

Кроме генетического метода при исследованиях применялась общая методологическая основа исследования - ландшафтный подход, в котором ландшафтному анализу подвергаются геосистемы различных рангов и в конечном итоге дается та или иная географическая оценка ландшафтного пространства объекта исследования, а полученные результаты анализа, синтеза и оценки применяются для решения задачи районирования территорий.

Значимым является то, что в основу рассмотрения таксонов районирования (ландшафтов, округов, провинций, областей), положены многолетние авторские полевые геолого-географические и географические научные и производственные исследования обширной территории окраинной зоны Востока России, которые в свою очередь включают полевые исследования Сихотэ-Алинской, Сахалинской, Камчатской, Анадырской ландшафтных областей [3-5] и материалы тематических научно-производственных работ по геологическим и палеогеографическим реконструкциям, проведенных при исследованиях на 
выявление месторождений полезных ископаемых (материалы хранятся в архивах Дальневосточного комитета по природопользованию) В целом отметим, что весь полученный полевой и научный материал по ландшафтам анализировался на междисциплинарном уровне, осмысливался и формулировался и благодаря этому была определена научная и практическая географическая целостность континентального обрамления и сопряженных с ним окраинных морей Тихого океана, выделенных таксонов районирования Тихоокеанского ландшафтного пояса и важность их для выполнения задач освоения высотного обрамления и окраинных морей Тихого океана. При обосновании применения материалов по таксонам районирования при освоении окраинноконтинентальной переходной зоны к океану использовались материалы практической реализации ландшафтного подхода с применением ландшафтной индикации в различных областях природопользования [8-11]. Особо отметим, что для определения региональной и планетарной ландшафтной целостности таксонов ландшафтов, как структурных единиц Тихоокеанского ландшафтного пояса соизмеримых с фокусом максимального взаимодействия океана и Азиатского континента, применены материалы авторских палеогеографических исследований. Применены результаты геологических и палеогеографических реконструкций по установлению генезиса, состава и тектонической эволюции фундамента ландшафтов. Применялась авторская концепция геодинамической эволюции зоны перехода Азиатского континента к океану [6.7] (рис. 2).
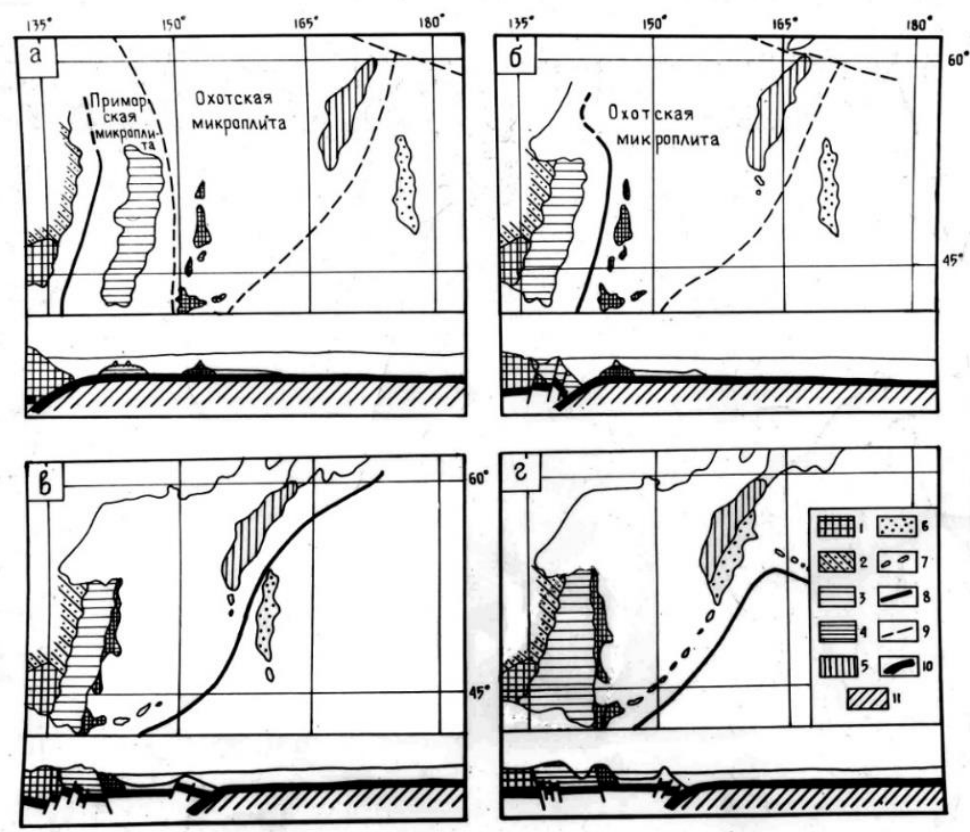

Рисунок 2. Карта положения и эволюции основных палеоструктур и сопряженных с ними элементов зоны перехода северо-востока Азии к Тихоокеанской плите. 1 - Ханкайский массив. 2 - пассивная палеоокраина Бикино-Баджало-Нижнеамурской зоны. 3 - Приморское палеоплато Приморской микроплиты с атоллами и рифовыми постройками на вершинах гор. 4 - Хоккайдо-Сахалинский палеохребет юго-западной части Охотской микроплиты с атоллами и рифовыми постройками на вериинах гор. 5 - Западно-Камчатское поднятие. 6 - Восточно-Камчатское поднятие. 7 - современная вулканическая дуга. 8 - сейсмофокальная зона. 9 - предпологаемые границы микроплит. 10 - океаническая кора. 11 -мантия в океане. а, б, в, г-положение палеоструктур в: а-домеловое время, б - бериасе, в-валанжин-датское время, г - в палеоцен-эоцене

Эволюция на примере Сихотэ-Алиня, Сахалина, Хоккайдо и прилегающих областей разделяется на два генеральных этапа: аккреционный и постаккреционный. Аккреционный отвечает аккреции геолого-структурных подразделений Тихоокеанской палеоплиты к палеоконтиненту. Фациальный анализ, сравнение состава и возраста стратифицированных комплексов, тектоники и магматических парагенезисов показывает, что в зоне перехода аккреция происходит не однократно. Одна из них соответствует аккреции в домеловое время 
Приморского палеоплато к активной окраине Ханкайского массива в Приморье и далее на север к окраине, представленной океаническими и шельфовыми образованиями основания Бикино-Байджальской зоны. Палеоплато представляет собой положительное геолдогоструктурное подразделение Тихоокеанской палеоплиты и если сравнивать с современными плато, то имело особенности.

Палеогеографический анализ среднепалеозойско-кайнозойских вещественных комплексов Сихотэ-Алиня, островов Сахалин и Хоккайдо, геофизические материалы и суммарная мощность толщ показывает, что Приморское палеоплато имело увеличенную мощность коры, около 20 км На плато существовали вулканические острова, поднимались отдельные вершины, часть которых несло атоллы и рифы, блоки, глыбы и обломки которых сейчас наблюдаются в вещественных комплексах Краевого Сихотэ-Алинского офиолитового шва, Ковалеровском, Ольгинском, Дальнегорском выступах фундамента Сихотэ-Алиня, а также островов Сахалин и Хоккайдо.

Другой этап аккреции отвечает аккреции в докайнозойское время к сформировавшейся в меловое время активной окраине (восточная окраина Приморского палеоплато) более молодых геолого-структурных подразделений Тихоокеанской плиты. На Сахалине произошла аккреция палеохребта, на что показывает присутствие в вулканогеннокремнисто-терригенном и других комплексах вулканитов близких к вулканитам современных хребтов Тихоокеанской плиты. Таким образом, можно говорить, что положительные геолого-структурные подразделения Тихоокеанской плиты в аккреционный этап не субдуцируются, а аккрецируются, интенсивно тектонизируются, наращивают континент и в дальнейшем представляют фундамент соответствующих киммерийскоальпийских складчатых горных систем.

Постаккреционный этап характеризуется дальнейшим «созреванием» (континентализацией) соответствующих нарастивших континент микроплит. Он характеризуется формированием отличающегося по возрасту, составу, мощности чехла, уже ставших фундаментом микроплит. В южном Сихотэ-Алине чехол представлен несколько километровыми меловыми терригенными, часто малассоидными толщами Главного синклинория, на о. Сахалин кайнозойскими полифациальными вещественными комплексами и т.д.

Дальнейшая эволюция фундамента характеризуется формированием сводовых поднятий и опусканий и образованием ландшафтных структур.

В целом важно отметить, что при палеогеографических исследованиях и районировании использовались также материалы, полученные по итогам многочисленных экспедиций на Сахалине, Камчатке, Чукотке и других территориям и, в частности, новые векторно-слоевые картографические материалы по отдельным регионам зоны континентального обрамления (сихотэ-алинской, сахалинской и др. ландшафтным областям). Использовались материалы практической реализации ландшафтного подхода с применением ландшафтной индикации в различных областях природопользования, материалы по организации и структурам ландшафтов и профилям через континентальное обрамление, в которых отражено установленное нами внутреннее содержание ландшафтов территории пояса в системе ландшафт, вид, род, подкласс, класс, округ, провинция, область, пояс, а также частные материалы по орогенным таксонам ландшафтов Тихоокеанского ландшафтного пояса России (DOI: 10.35735/tig.2021.17.72.023, DOI: 10.18411/lj-03-2021-33). Использовался материал по выделенным высотно-ландшафтным комплексам горных, островных, озерных геосистем, а также их водосборов (DOI: 10.24411/9999-039A-202010075).

Весь имеющийся материал анализировался на основе сопряженного анализа и синтеза межкомпонентных и межландшафтных связей с учетом окраинно-континентальной дихотомии и данных по орогеническому, орографическому, климатическому факторам формирования географически единых территорий. Получены были следующие результаты. 
Результаты. В результате исследований на основе комплексного синтеза, анализа и осмысления научных и полевых материалов по ландшафтам и по ландшафтному районированию морских и горных территорий Тихоокеанского ландшафтного пояса России сформулировано ландшафтное генетическое единство Тихоокеанского ландшафтного пояса как единой горной и морской диалектической пары геосистемы Восток России-Мировой океан.

При выполнении задачи изучения организации и районирования установлена важность и необходимость применения комплексного междисциплинарного уровня мышления, синтеза, анализа и формулирования результатов ландшафтного моделировании областей, провинций, округов морских территорий ландшафтного пояса.

Проведено изучение организации и ландшафтное районирование сверху вниз и выделены ландшафтные области, провинции и округа морского звена Тихоокеанского ландшафтного пояса России

(рис. 3, таблица 1).

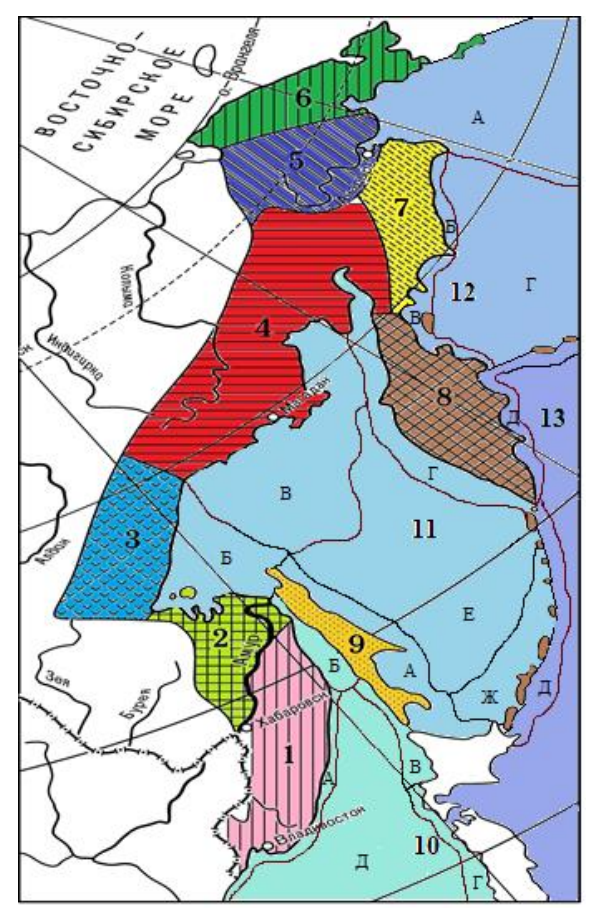

Рисунок 3. Карта Тихоокеанского ландшафтного пояса России, его областей, провиницй (Старожилов, 2021)

Области пояса: 1. Сихотэ-Алинская; 2. Нижнеамурская; 3. Приохотская; 4.Кольмская; 5. Анадырьская; 6.

Чукотская; 7. Корякская; 8. Камчатско-Курильская; 9. Сахалинская; 10. Японская; 11. Охотская; 12.

Беринговая. 13. Тихоокеанская; Провинции областей окраинных морей: японской (10): шельфовые - $A$.

Западнояпонская; Б. Северояпонская; В. Восточносахалинская; Г. Восточнояпонская; морская: Д.

Центральная японская; охотской (11): шельфовые: А. Западноохотскосахалинская; Б. Западноохотская; В.

Кольимскоохотская; Г. Охотскокамчатская; Д. Камчатскокурильская; Ж. Охотскокурильская ; морская: Е.

Центральная охотская; беринговой (12): шельфовые: А. Командорскоберинговая; Б. Корякскоберинговая; $B$.

Камчатскоберинговая; Д. Тихоокеанскокурильскокамчатская; морская: Г. Центральноберинговая;

Таблий 1

Примеры областей, провиниий морского звена Тихоокеанского ландшафтного пояса России

\begin{tabular}{|c|c|c|}
\hline Пояс & Область & Провинцчия \\
\hline \multirow{2}{*}{ 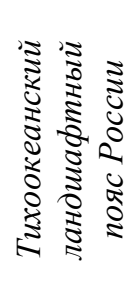 } & Японская & $\begin{array}{c}\text { Шельфовые: А. Западнояпонская; Б. Северояпонская; В. } \\
\text { Восточносахалинская;Г. Восточнояпонская; морская: Д. } \\
\text { Центральнояпонская; }\end{array}$ \\
\hline & Охотская & $\begin{array}{c}\text { Шельфовые: А. Западноохотскосахалинская; Б. } \\
\text { Западнооотская; В. Кольцскоохотская; } Г \text {. } \\
\text { Охотскокамчатская; Д. Камчатскокурильская; Ж. } \\
\text { Охотскокурильская; морская: Е. Центральная охотская; }\end{array}$ \\
\hline
\end{tabular}




\begin{tabular}{|c|c|c|}
\hline \multirow{2}{*}{ Беринговая } & $\begin{array}{c}\text { Шельфовые: } \text { А. Командорскоберинговая; Б. Корякскоберинговая; } \\
\text { B. Камчатскоберинговая; Д. Тихоокеанскокурильскокамчатская; } \\
\text { морская: Г. Центральноберинговая; }\end{array}$ \\
\hline
\end{tabular}

При этом важно отметить, что именно комплексный междисциплинарный многокомпонентный подход позволил подойти к составлению полноценных моделей природы («природного фундамента»), включающих результаты взаимодействия, взаимопроникновения костной и биокосной природы, для составления гармонизированных с ней моделей пространственного развития и освоения территорий.

Установлено, что при изучении организации и районировании ландшафтов сверху вниз морских, как и континентальных, территорий во взаимодействии, взаимообусловленности и взаимопроникновении с другими составляющими ландшафт компонентами играет фундамент. Нами определено, что он как компонент ландшафтной системы отвечает за ландшафтную сопряженность морских и континентальных классификационных единиц ландшафтов. В частности, например, в результате палеогеографических исследований установлено, что в сопряжении Японской и Сихотэалинской ландшафтных областей участвует единое Приморское палеоплато, а в сопряжении Охотской и обрамляющих её континентальных ландшафтных областей участвует единое Охотское палеоплато.

Установлено также, что в горных и морских ландшафтных геосистемах в условиях окраинно-континентальной дихотомии при районировании возрастает роль анализа тектоники и вещественного состава фундамента. Тектонический режим определяет потенциал динамики и стабильности, а вещественные комплексы, являясь поставщиками материала (геохимического, минерального и т. д.), характеризуют вещественноматериальный потенциал геосистем. Речь идет о направляющем геологическом потенциале развития ландшафтов, о геологическом качестве, которое понимается как способность фундамента ландшафтов за счет собственного геологического природного потенциала в течение длительного времени сохранять и поддерживать динамику развития и вещественногеохимический потенциал территории. В целом при проведении исследований установлено направляющее значение геологического потенциала развития ландшафтов, в обособлении и дальнейшем формировании генетически единых ландшафтных единиц Тихоокеанского ландшафтного пояса России.

При изучении организации и районировании в результате палеогеографических и геологических реконструкций [6,7] установлена генетическая сопряженность фундамента горных и морских ландшафтных территорий и это в свою очередь свидетельствует об диалектической сопряженности современных рассматриваемых ландшафтных структур. Поэтому понимая генетическую и ландшафтную их сопряженность на уровне областей, провинций, округов, в наших исследованиях мы предлагаем не вводить в название новых наименований, а оставить сопряженные с континентальными, то есть мы оставляем для наименования ландшафтных единиц морских акваторий Тихоокеанского ландшафтного пояса названия область, провинция, округ.

Заканчивая важно отметить, что, как показали исследования Тихоокеанского ландшафтного центра ДВФУ в освоении геосистемы континент-океан, установление статистических данных по таксонам ландшафтов и морфологическому строению территорий- это только первый этап ландшафтного изучения морского звена Тихоокеанского ландшафтного пояса. Специальное изучение ландшафтной школой профессора В.T. Старожилова фундаментальных направлений изучения ландшафтов и их картографирования установлено то, что кроме морфологического направления выделяются: индикационное, ландшафтных узловых структур освоения, планирования и проектирования. Отмечается, что все они сопровождаются составлением векторно-слоевых разномасштабных индикационных, узловых структур освоения, планирования и проектирования векторнослоевых ландшафтных карт. Поэтому для получения полной характеристики объектов 
внимания государства фундаментальные исследования морских территорий должны быть продолжены в отмеченных выше направлениях. Такие работы уже проводятся в Тихоокеанском международном ландшафтном центре ДВФУ под руководством профессора В.Т. Старожилова.

Также подтверждается и отмечается, что применение материалов по изучению организации и районированию геосистемы континент-Мировой океан направлено на рациональное освоение и использование территорий, минимизацию глобальных и региональных последствий изменения природы и общества, поиск и внедрение инновационных подходов в устойчивом, экологически сбалансированном и безопасном развитии обширного региона.

Заключение. Констатируется, что на основе научных и полевых исследований Тихоокеанского международного ландшафтного центра ДВФУ и Ландшафтной школы профессора Старожилова получен прежде всего фундаментальный статистический и картографический ландшафтный материал по ландшафтному обрамлению Тихого океана. На его основе формулируется и картографируется в ландшафтных границах географически и ландшафтно-целостные таксоны иерархической системы ландшафтов морского звена Тихоокеанского ландшафтного пояса геосистемы континент-Мировой океан: тип, округ, провинция, область, пояс.

На основе полученных и формулируемых итогов синтеза, анализа и оценки данных установлено, формулируется и утверждается, что в Российской науке необходимо на основе применения ландшафтного метода выделять округа, провинции, области как индивидуальные важные таксоны окраинных морей Тихого океана. Они выделяются как внутреннее содержание Тихоокеанского ландшафтного пояса, как природные таксоны структур и организации диалектической пары геосистемы континент-Мировой океан. Рекомендуется применять их базовый комплексный характер как таксоны структуры ландшафтной основы-модели освоения и использовать эти материалы как опорный природный «фундамент» к пространственному развитию территорий. Ландшафтные округа, провинции, области рассматривать как единицы природного «фундамента» для построения гармонизированных с континентальной природой и океаном региональных и планетарных научных и практик-моделей: индикационных, картографических, экологических, биологических, биогеохимических, биоресурсных, минерально-сырьевых, экологических, сельскохозяйственных, градостроительных и других отраслевых моделей освоения, в целом пространственного развития и освоения этой обширной тихоокеанской зоны.

$$
* * *
$$

1. Мильков Ф.Н. Ландшафтная география и вопросы практики. - М.: Изд-во «Мысль», 1966. - 256 с.

2. Солнцев Н.А. Учение о ландшафте (избранные труды).-М.: Изд-во МГУ, 2001.-384 с.

3. Старожилов В.Т. Природопользование: практическая ландшафтная география. / учебник. Школа естественных наук ДВФУ, Тихоокеанского международного ландшафтного центра, Школа естественных наук ДВФУ. Владивосток, 2018. 276с

4. Старожилов В.Т. Эколого-ландшафтный подход в формировании региональной экологической политики на территории стран АТЭС / В сборнике: Шестые Гродековские чтения. Актуальные проблемы исследования Российской цивилизации на Дальнем Востоке. межрегиональная научно-практическая конференция. Правительство Хабаровского края. Хабаровск, 2009. С. 24-28.

5. Старожилов В.Т., Зонов Ю.Б. Ландшафтные предпосылки устойчивого развития территорий. / В сборнике: Природа без границ. Материалы I Международного экономического форума. Администрация Приморского края. 2006. С. 261-265.

6. Старожилов В.Т. Окраинно-континентальный ландшафтный пояс как географическая единица Тихоокеанской России / В сборнике: Устойчивое природопользование в прибрежно-морских зонах. Материалы международной конференции. 2013. С. 38-42.

7. Старожилов В. Т. Картирование ландшафтов и геодинамическая эволюция фундамента Дальневосточных территорий/ В. Т. Старожилов // Ноосферные изменения в почвенном покрове: материалы Международной научн. конф. Дальневост. гос. ун-т: Под общей редакцией: А.М. Дербенцева. 2007. С. 174-178.

8. Старожилов В.Т., Дербенцева А.М., Ознобихин В.И., Крупская Л.Т., Степанова А.И. Ландшафтные условия развития эрозионно-денудационных процессов юга Дальнего Востока. Владивосток, 2008. 
9. Старожилов В.Т. Эколого-ландшафтный подход к промышленным территориям юга Дальнего Востока // В сборнике: Современные геофизические и географические исследования на Дальнем Востоке России. материалы 9-й научной конференции, Владивосток: конференция приурочена к Всемирным дням воды и метеорологии, а также к 110-летию ДВГУ и 45-летию ГФФ. Дальневосточный государственный университет, Институт окружающей среды ; под редакцией Н. В. Шестакова. Владивосток, 2010. С. 155-158.

10. Старожилов В.Т. Проблемы ресурсопользования, структура и пространственная организация ландшафтов приокеанских Дальневосточных территорий // В сборнике: Науки о Земле и отечественное образование: история и современность. материалы Всероссийской научно-практической конференции, посвященной памяти академика РАО А. В. Даринского. Российский государственный педагогический университет им. А. И. Герцена, факультет географии. 2007. С. 310-312.

11. Старожилов В. Т. Ландшафтные геосистемы Сахалинского звена Тихоокеанской России // В сборнике: Научная дискуссия: гуманитарные, естественные науки и технический прогресс. Материалы VII Всероссийской научно-практической конференции. 2015. С. 54-64.

\section{Bolotin S.N., Khalyapina A.V., Mukvich E.S., Semenova S.N. To the Question of the Study of the Ecological State of Steppe Soils}

Kuban State University

(Russia, Krasnodar)

doi: 10.18411/trnio-12-2021-334

\section{Abstract}

This article presents conclusions about the ecological state of steppe soils, which were obtained as a result of the EPR (Electronic paramagnetic resonance) spectroscopy method and the microbiological method. The selection of soil samples for the study was carried out in the steppes of different territories: Voronezh region; Rostov Region; Volgograd Region; Republic of Kalmykia. It was revealed that free radicals were present in all soil samples.

Keywords: EPR (Electronic paramagnetic resonance) spectroscopy, free radicals, microbiological soil activity, cellulose, ecological state of soils, steppe, laboratory.

\section{Аннотация}

В данной статье представлены выводы об экологическом состоянии степных почв, которые были получены в результате проведения метода ЭПР спектроскопии и микробиологического метода. Отбор образцов почв для исследования проводился в степях на разных территориях: Воронежская область; Ростовская область; Волгоградская область; Республика Калмыкия. В результате проведения опыта было выявлено, что свободные радикалы присутствуют во всех образцах почвы.

Ключевые слова: ЭПР спектроскопия, свободные радикалы, микробиологическая активность почв, целлюлоза, экологическое состояние почв, степь, лаборатория.

\section{Introduction}

Man is constantly changing natural ecosystems to meet his needs. Human economic activity entails drastic changes in all components of biocenoses. The plowing of the steppes gradually leads to the disappearance of many elements of the former biocenosis, and the constant use of soils in agriculture sphere leads to their depletion of nutrients [3].

The current pace of road construction and operation, the increase in tourist facilities increases the burden on the environment. There are almost no studies devoted to assessing the resistance of soils to pollution by heavy metals. It is advisable to determine the degree of soil resistance to chemical pollution using biodiagnostic methods [5, 7].

\section{The description of the research}

The following equipment was used to study the soil in the laboratory of the Kuban State University: prepared material (soil); laboratory mortar and pestle; quartz cuvettes; scales; acetone; cotton wool [2]. 